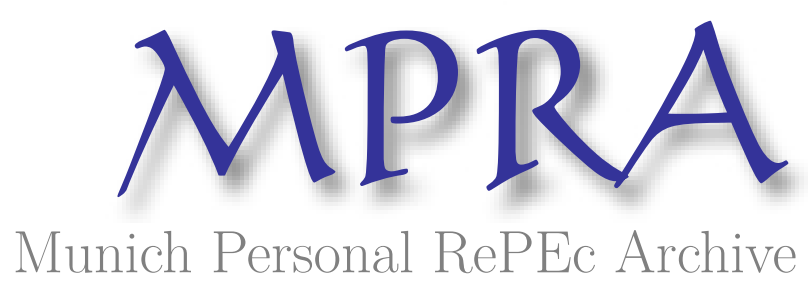

\title{
A Critical Overview of Islamic Economics from a Welfare-State Perspective
}

Soldatos, Gerasimos T.

2015

Online at https://mpra.ub.uni-muenchen.de/70066/

MPRA Paper No. 70066, posted 16 Mar 2016 23:55 UTC 


\title{
A Critical Overview of Islamic Economics from a Welfare-State Perspective
}

Gerasimos T. Soldatos, American University of Athens, 15232 Athens, Greece; soldgera@ yahoo.com

An earlier version of this article was published under the title: "A Welfare State Approach to Islamic Polity” by Political Sciences \& Public Affairs, 2015, 3(3), 180: 1-5

\begin{abstract}
This paper builds upon the following critique of Islamic economics: (a) Persistence on the literal interpretation of what the theology of Islamic law implies socioeconomically, (b) Rejection subsequently of the core western economic principle of homo economicus-cum-competition, though homo economicus behavior is innermost to absence of riba al-fadl (of exploitation in the goods markets) in the large at least impersonal markets of our times, (c) Rejection, because of the ahistorical view of the West and hence, of inability to realize that the Cold War European welfare state with a constitution inspired by social solidarity as it derives not politically but religiously from Islamic law, might be worth followed by Islam, and (d) Identification of riba an-nasiya (of exploitation in the financial markets) with zero interest rate charges and not with zero commercial bank seigniorage.
\end{abstract}

Keywords: Islamic economics, Deduction vs. theologically induced induction, Homo economicus, Riba (exploitation), Welfare State

JEL Codes: P51, D63, Z12, H11, P48, D64, B41

\section{Introduction}

The objective of this paper is to elaborate further upon the viewpoint of Islamic polity as a democratic welfare state. A short critical review of the salient features of Islamic economics is used to identify those principles that prompt such a view of the Islamic social economy in a way that is also compatible with "western economics". The issue of the compatibility between Islamic and western economics is important, because although Chaudhry (1999) and Gummi (2013), for instance, are among those who see the essence of the Islamic economic system to lie in welfare state considerations, they do so based mostly on Islamic imperatives. Such an approach offers a fragmentary rather picture of the Islamic welfare state and can obstruct the resemblance of the Islamic system contemplated with the western welfare state. Yet, both of these analytical drawbacks may be avoided if the common premises of the two kinds of economics that support the welfare-state stance are identified. The discussion in what follows is advanced under this understanding.

To start with, according to Khan (1987, pp. 21-22), economic interpretations based on Qur'an and Sunnah in early Islam are outdated and "A host of new questions in the contemporary life require the Shari'ah position but the scholars are unable to present an answer mainly because the existing methodology does not take them very long [far]". Indeed, judging from authoritative works on the subject like those of Ahmad (1994) and Zaman (2008), Islamic economics tries to infer principles from the examination of specific instances of specific Islamic law, Shari'ah applications in practice, and by examining the letter rather than the spirit of the code. It looks at the tree and not at the forest, but theologically, not in an Aristotelian fashion, which has proved to be counterproductive. The spirit of the code is looked upon theologically as Phillip (1990) inter alia observes, whereas it is considered to be 'dismal' in "find[ing] the secret of this Universe in 'supply and demand' " (Carlyle 1849, p. 353). Yet, this is what economics is by definition, and so what is really being done methodologically by this "theological" strand of Islamic economics is to be confusing apples with oranges and to be searching 
for instances in real life when the two coincide, and proceed next bottom-up to form Islamic economic principles.

Shams (2004) notes that there does exist a second, an analytical strand utilizing the methodology of mainstream Economics to tackle problems considered to be Islamic economic problems. And, he proposes a reconciliation of the two strands by using the concept of nafs (self-interest, so to speak), relating the functioning of an Islamic economy with the control of nafs. But, this approach "begs the question", because presumably the control is religiously induced. Islamic economics has to see things top-down, deductively, indeed, but non-theologically, abandoning the bottom-up, inductive, quest imposed by theology. Shari'ah may be the infallible law of God, but it was delivered under particular historical circumstances addressing literally only the people of those times. It trusts that future generations do have the common sense to comprehend its spirit and apply Shari'ah analogously depending on the circumstances prevailing each time as, for example, Azid (2010, pp. 169-171) does though as very timidly.

The reason is that he identifies the paternalist socioeconomic system implied by the religion more or less correctly, but he refrains from expanding on it, because he is preoccupied against homo economicus and cannot obtain subsequently the microeconomic underpinnings of the proposed system. The point is that there does exist a third, the promising approach to Islamic economics upon which this paper comes to capitalize. It is about a secularly paternalist socioeconomic system, with the paternalism adapted to modern circumstances like, for example, that in no way zakat, sadaqa, jizyah, and khums, can form the basis for modern tax revenue collection. A system instead of progressive taxes and of subsidies to the weak would be much closer to manifesting the spirit of Shari'ah in our times. Would it be fully compatible with Shari'ah if it was rationalized based not on the condemned by the law selfish homo economicus but on altruist homo ethicus (see e.g. Zamagni 1995)? Homo economicus is condemned by Veblen, Keynes, Simon, and others too, ( see e.g. Sen 1977), in the Aristotelian sense of "love of self in excess, like the miser's love of money; for all, or almost all, men love money and other such objects in a measure. And further, there is the greatest pleasure in doing a kindness or service to friends or guests or companions, which can only be rendered when a man has private property", (Politics, Book II, Part V).

That is, what is condemned is any manifestation of selfishness beyond that required to rationalize marketplace exchange. One lets be robbed if one is not selfish in the bazaar. Homo economicus behavior captures just that, it is a sine qua non of marketplace exchange, towards the minimization of Riba al-Fadl (exploitation in the goods market). This exploitation is doomed by Islamic law, but equally doomed by Islamic economists is the behavior complying with this dictum of the law! It is therefore correct to be postulating a homo economicus or nafs analytically when trying to rationalize market exchange, though it may be improper to be extending it unnecessarily to the rest of economics. As we shall see later in the text, this is important because otherwise Adam Smith's (1776) "invisible hand" is stripped of its morality (Evensky 1993, 2005), let alone that normative concepts like fairness and envy-freeness could not be tackled by mainstream economics.

The matter is that considerations like these pinpoint to the presence of a lot of common ground between mainstream and Islamic economics, since Islamic individuality and the Aristotelian sense of it are quite alike. And, hence, it is advisable methodologically to investigate the relationship between Shari'ah's paternalist socio-economic system and Western paternalism in an effort to identify that particular Western system that would be compatible with Islamic law if the system's politically motivated constitution was replaced by a Shari'ah inspired one. This is the task of the next section: "To clarify Islamic economic's Weltanschauung and develop an appropriate content and form" (Mahomedy 2013, p. 556). Shari'ah is divided in two parts, the "non-financial" one and the "financial" one, the one pertaining to the scope and structure of the financial system. The non-financial part is easy to appraise because it is permeated by the quest for maximum individual and societal welfare under justice. What 
is really sought is the avoidance of resource waste in production and consumption (efficiency) under egalitarian and envy-free income distribution.

Indeed, "Muslim economists have the consensus that the main objective of Islamic Economics is to establish social justice, elimination of poverty, tangible reduction in economic disparities,..." (Azid 2010, p. 169-170). We start the discussion in the next section taking this principle for granted, which explains why our approach to Islamic law is a top-down one. The discussion takes the form of challenging stereotypes in Islamic economics in the light of Western experience; stereotypes as expressed by one relatively recent authoritative and influential work in Islamic economics by Zaman (2008). Section 3 concludes this paper elaborating upon the difficult "financial" part. The abolition of Riba an-nasiya (exploitation in the money market), or just riba, is needed if the financial system is not to be impeding efficiency, egalitarianism, and envy-freeness independently of whether this abolition is a matter of Shari'ah or makruh. The difficulty lies in the application of riba in practice, which recent developments in monetary theory and policy make it more likely. The overall idea worked out in this paper is European welfare-state workings with zero commercial bank seigniorage based on an Islamic law rather than political-ideology minded constitution, and allowing for political democracy as well. It is an idea which derives from the proposed "top-down approach" and may form the basis for future research in Islamic Economics.

\section{Islamic Economics: Islamic Version of the European Welfare State?}

One of the stereotypes of Islamic economics has been its static and uniform view of the West. A brief overview of the dynamics that led to modern West and a classification scheme of the current western political economy would certainly help see how exactly Islamic economics differentiates itself from this economy. Let us first address the issue of the history behind modern West, which Islamic economists neglect. For example, Zaman (2008, Abstract) writes: "Modern Western political, economic and social structures have emerged as a consequence of the repudiation of religion, and are based on secular principles. Many of these are inimical to Islamic principles, and cannot be adapted to an Islamic society." It should be borne in mind that religious wars in Europe devastated the continent, and the modern West is the result of these wars. Religious intolerance and putting religion in the service of regional interests were ruining Europe for centuries (see e.g. Holmes 1988). The so-called Middle or Dark Ages left a scar on Islam too, through the Crusades because these campaigns were one of the extravagancies of Middle Age Christianity. This, until Europeans started having contact with the ancient Greek thinking preserved by the Muslim scholars. Religion eventually was replaced by political ideologies given that they all have their place in a democracy and that voters can be of any religious background thus taking away interreligious tensions. And, to fully insulate the election outcome from religious differences, the separation of the republic from the Church was proclaimed.

Two things now need to be noticed. First, that the historical circumstances surrounding this development were such that Adam Smith's "invisible hand" would come handy to the big capital and its apologizers to be misinterpreted purposefully to mean the pursuit of egoistic self-interest (Kennedy 2009). And, second, that we are talking about a development in a Christian world anyway, a world in which one of its fundamentals is modest income inequality, and politico-economic theses should not be challenging the fundamentals of the Faith. This incompatibility triggered a growing and long-lasting class conflict in the place of the old religious conflict. Unionism, Fascism, and Communism became eventually the apologizers of the "revolting" with the atheism of Fascism and Communism reflecting the disappointment with the non-interventionism of the Church. In so far as Vatican is concerned, the incident of World War II made it clear that it does have to intervene in two fronts: One against the expansion of Communism in Europe by endorsing silently a Christian-democrat movement, and the other against the American imperialism in Latin America by tolerating the militancy of the Catholic clergy there. The conclusion of these historical developments following the Middle Ages and having culminated in the two World Wars, is the modern post-World War II welfare state, the two European types of it, the Christian and Social Democratic ones, as identified by Ferragina et al. (2015). 
The genuine "welfare state" and "mixed economy" has been the one during the Cold War, shaped under the fear of the influence of Soviet propaganda on the Western voter (see e.g. Eichengreen 1992). One is inclined then to ask: Does Islamic economics refer to a third type of mixed economy given the history of the Muslim world? May Islamic law be interpreted to imply a socioeconomic order akin to Europe's welfare-state, under its genuine Cold War form, reflecting at the same time this thesis the emancipation from the former non-welfare state European oppression?: "Muslim societies achieved freedom from colonial rule in the first half of the twentieth century and sought to construct institutions in conformity with Islam. The development of Islamic economics is part of this process of transition away from Western colonial institutions."(Zaman 2008, Abstract). Indeed, the difference between a democratically run and a religiously run welfare state lies only in the "softness" of paternalism (as contemplated in Feinberg (1986)), not on paternalism itself. But, Islamic economists are not clear if a welfare state is what they have in mind. They are confused perhaps because of the non-European influence in their thinking, given that America too, is considered to be a welfare state, a third type of it, the Liberal one (along with Canada, Australia, and Japan) while the United Kingdom (Ireland, and New Zealand) comprise a fourth type, the unclassified one. Yet, the truth is that the last thing a supporter of unfettered capitalism like America and the United Kingdom could be classified is as a welfare state. It should be noticed that these two last types of welfare state might be referred to uniformly as the Anglo-colonial legacy of classical liberalism, turned now into neo-liberalism, preserving the term welfare state only for mainland Europe with its traditional social liberalism.

And, it is perhaps this legacy, not the social-welfare minded mainland Europe, not the balance between individual liberty and social justice that Islamic economists dismiss as workable examples for a Muslim social economy. The classical and libertarian liberal perspectives of the political economy have always been foreign to mainland Europe where private businesses are not seen as panacea. To establish our thesis here that Islamic economics is the Islamic version of (Cold War) European welfare state, let us see which exactly of the secular principles of the broadly defined West cannot be adapted to an Islamic society. Is the mentality of Islamic economics similar to having the Christian Church denounce mainstream economics on the grounds that this economics does not acknowledge that Christians should not be eating meat on Fridays? Lumping Islam and Christianity into one term, religion, there are two ways to put the connection between religion and economics. One is the hard paternalist way whereby the meat market for Christianity or the pork, for instance, market for Islam is abolished altogether. The other is the soft paternalist's way whereby the overall market does continue operating subject only to the distortions originating in the cosmic mandates of religion as practiced by the customer. Which of the two is Islamic economics? The answer lies in: "selling products which lead to moral corruption would not be permissible in Islamic law" (Zaman 2008, Abstract). Does Islamic economics turns out to be hard paternalist economics as opposed to the economics of the welfare-state model of the market (e.g. of the social market) and of the distortions of this market from those believers, who actually choose to practice their religion?

To answer this question, let us discuss the paternalism in Islamic economics from a different point of view. Zaman (2008, Abstract) continues writing: "Neoclassical theory is centered around the acquisitive instinct of humans, and makes competition the driving force of economic analysis. Islamic approaches foster cooperation and encourage generosity as the fundamental principle for handling economic affairs." This quotation is about the matter of selfishness. We saw in the introductory section that intentional non-cooperation is one thing and mutually beneficial unintentional interaction in the marketplace driven by the homo economicus instinct is another. Islamic economics does not differentiate between the two, and exalts the homo ethicus who is indeed documented anthropologically (Mauss 1970), psychologically (Dunning 2011, Roberts 2011), and sociologically (American Sociological Association: Altruism, Morality and Social Solidarity), outside the sphere of religion. As a matter of fact, it is the instincts of cooperation and altruism that the European welfare state tries to spread through its social solidarity institutions. But equally well an instinct is the individualism of not wanting to fool away, to be outsmarted in the bazaar. This natural marketplace rationality is what homo economicus is all about, a tractable analytically personality, seized by Neoclassical economics. 
We are referring, of course, to that institutional arrangement of the marketplace in which acute sensitivity to budget constraints and opportunity costs can be exhibited. Homo economicus reflects this sensitivity in the Walrasian auction and Edgeworth tâtonnement arrangements and practically, in the extensive in general impersonal markets of our times. It is under such exchange arrangements and not under bilateral bargaining that homo economicus leads to exploitation, to riba al-fadl nullification through competition. Under bilateral bargaining, it is known since Aristotle's Nicomachian Ethics, that a weak homo economicus will be victimized almost certainly by a stronger one and reciprocal justice is needed in the exchange if the interaction is to be mutually beneficial. That is a homo reciprocus (in the Aristotelian and not Old Testament sense) is needed to ensure fairness, and the necessity of a homo Islamicus might as well justified accordingly. So, when this paper postulates the compatibility of homo economicus with any of the Abrahamic religions, it does so under these words of caution, it is referring to the modern world.

In any case, this "homo" has nothing to do with intentional non-cooperation and this is why Adam Smith's invisible hand exchange has its moral value. It is wrong to put the Smithonian exchange between the shivering baker and the hungry tailor under the dilemma egoism versus cooperation and generosity: "In Smith's story ethics is the hero - not self-interest or greed - for it is ethics that defend the social intercourse from the Hobbesian chaos" (Evensky 1993). The error is very vividly illustrated through the bar scene from the 2001 movie "A Beautiful Mind" regarding the life of John Nash: The actor (Nash) says to his friend in the bar: "Adam Smith said, the best result comes from everyone in the group doing what's best for himself, right? That's what he said, right? Incomplete. Incomplete! The best result will come when everyone in the group doing what's best for himself - and the group"; (see: http://adamsmithslostl egacy.blogspot.gr/2007/12/tale-of-two-views-on-john-nash.html). This comment by Nash is made to clarify what actually Adam Smith meant by the term "invisible hand'; and he answers that it certainly did not mean intentional non-cooperation. It is this incomplete interpretation of the term that continues to be put forward by the big capital, which may be another source of confusion for the view Islamic economics holds regarding homo economicus and the invisible hand.

In the market, cooperation is motivated by selfishness, elsewhere cooperation may be motivated by selflessness; the focus is in individual plus social-welfare enhancing cooperative outcomes, not on their motivation. And, when neither the self-interest nor other "cooperative motivations" can be exhibited, and collective action is needed to maintain and promote individual and social welfare, for what else than cooperation and generosity the welfare-state principle of social solidarity, the French Fraternité stands? Fraternité, especially, recognizes the manifestation of individuality, of egoism only to the extent community harmony is preserved, possibly under a Christian brotherhood (Nora 1997). Philanthropy, organized or not, is certainly welcome, since it can enhance individual and social welfare by filling in the breaches in the social economy network that the welfare state cannot for some reason handle. Under these circumstances, the only difference I see between this political economy and the Islamic one is, epigrammatically, of course, the replacement of the ideologically motivated principle of social solidarity by Shari'ah, a welfare state with a constitution inspired by social solidarity as it derives not politically but religiously from Islamic law. The parallels are there to see.

The Islamic economics welfare state is one of soft paternalism as its European counterparts. But, to be sure, let us ask how exactly Islamic economics distances itself from the welfare-state political economy? Zaman (2008, Abstract) would say: "Human beings have potential for good and evil, and are free to choose between the two; their behavior is not subject to mathematical laws postulated by neoclassical economic theory. The main message of Islam is that we must strive to achieve the potential for good both at the individual and at the social level. Behavior in the economic realm is also governed by this goal." We have already dealt with the "neoclassical" and, of course, mathematical modeling would be especially welcome by an Arab, honoring Arab mathematical tradition. So, the focus is on how to achieve the potential for good in practice if not through consensus. Coercively, dictatorially, by fanaticizing the faithful, by turning one against the other in a race for religious superiority? As it has already been mentioned, Christianity in Medieval Europe did try so for centuries, 
and the lesson was bitter for all. The welfare-market system and democracy are the ultimate result of this hard lesson. Is a repetition of the dark ages by Islam this time, what Islamic economists have in mind? No, certainly not, and from this point of view of absence of fanaticism either on the part of the Islamic economics state or on the part of its subjects, Islamic economics appears to be sort of soft paternalism. It does satisfy Pogge's (2008) desiderata for paternalism to be soft and effective as can be seen from the scope of Islamic economics.

Let us verify it. Zaman (2008) continues: "Islamic law (Shari'ah) provides the framework for all activity within an Islamic society. In the economic domain, Islamic law regulates both methods by which money may be earned and also the ways it may be spent. Acquisition of wealth is permissible only in ways which are just to all parties concerned; exploitation, arbitrary taxation, and individual profit resulting in social harm is not permissible in Islamic law." As it has been explained above, exploitation, arbitrary taxation, and harmful profitmaking were indeed the case in pre-welfare state Europe, and exploitation and uncontrolled profitmaking continue to be the case in the Anglo-colonial legacy. It is a legacy which after the collapse of Soviet Union wants to globalize increasing socioeconomic inequality in the name of neo-liberalism, it has actually managed to do so if one judges, for example, from Piketty (2014), and it has been challenging relentlessly and victoriously the Cold War welfare state in continental Europe, having put Europe under the predicament of whether it will continue resisting neo-liberalism to save whatever welfare institutions remain operational or whether it will align fully with the "neo-Anglo-American" paradigm.

Setting aside the author's pessimism about the future, the truth of the matter is that the concept of absence of riba al-fadl has been preoccupying in the form of "just price" any type of economic thinking since the times of ancient Greece (Ekelund and Hébert 2014). Also, any textbook in economics principles condemns anti-social welfare phenomena, and only neoliberal Americans do not see the harmfulness in harmful profitmaking. The point again is how exploitation, arbitrary taxation, and excess profitmaking can be confronted in practice: Through a command social economy or through a European welfare state, a welfare-state regime cautioning against neo-liberalism? The Soviet Union was a command-economy attempt towards that direction and failed. So, what is left as an option is the welfare state of cold-war Europe. Is such a state what Islamic economists have in mind qualified religiously? This indeed cannot be but the only case from the viewpoint of purely economic content, and guided by Islam rather than by some political ideology. Guided, from a soft paternalist perspective, unwilling to mimic "fervent fundamentalist Christian factions [in America that] relate literal biblical interpretations to contemporary political issues in order to discipline members to support conservative political causes" (Raines and Jung 1986, p. 429). Phenomena of literal interpretations of writings to predispose animosity on the part of this or that minority exist and will exist from time to time everywhere, but should not be influencing prudent policymaking by shaping public opinion and action.

The cosmic implications of sacredness that Nasr (1989) suggested that should be imbued into Western materialism by Islamic economics are already incorporated by the European welfare state, deriving in content not religiously but ideologically from the LEF principles. Several thus other questions preoccupying Islamic economics as nicely are surveyed by Mahomedy (2013) are answered at the same time; important practical questions like the primarily public or primarily private character of the Islamic economy and the capitalist or socialist nature of it. Even more importantly, the question of what true Islamic order is answered, the question, which according to Mehrdad (1993) made Iran abandon the term "Islamized economy", because of disagreement in its content. The task of Islamic economics is to answer this fundamental question, not to develop an Islamic economic theory. There cannot be any genuinely Islamic economics, since there cannot be any homo Islamicus: the nexus homo economicus - riba al-fadl is as unbreakable as the nucleus of the atom when interaction is noncoercive. Consequently, the focus should be the Islamic order under which such interaction takes place. The Islamist Welfare State this paper asserts that this order is. 
There remains one last point that needs to be addressed to make this thesis solid. I have chosen to close this section with this point, because it is the fresh air that Islamic economics bring to European welfarestate economics, by raising a neglected but very important religious, philosophical, and politicoeconomic principle for Europe as well, namely that "property must be used in ways beneficial to the individual and society" (Zaman 2008, Abstract). The West has chosen to be turning a blind eye towards this principle just because of the political power of the rich whose possessions are too large be benefiting them, and society is not let to turn such possessions into collective assets. According to Locke (1952 [1690], 19): "The same law of nature that does by this means give us property does also bound that property too. 'God has given us all things richly' (1 Tim. vi. 17), is the voice of reason confirmed by inspiration. But how far has he given it to us? To enjoy. As much as any one can make use of to any advantage of life before it spoils, so much he may by his labor fix a property in; whatever is beyond this is more than his share and belongs to others. Nothing was made by God for man to spoil or destroy." And, Friedman $(2001,4)$ adds: "It was the invention of money as a store of wealth that, to Locke's regret, allowed some to monopolize a 'disproportionate and unequal possession of the earth,' giving them power over others." That is, no one should have more property than can be used for one's own consumption and moreover, as a social relationship, property becomes contested ground (see Fried 1998). But, under the influence of big capital in the United States, these principles were carefully swept under the rug. It is time to reconsider at least in welfare-state Europe.

\section{Further Remarks}

In a few words, the "non-financial" part of Islamic economics was not as well developed as the "financial" one, because "The whole concept [of an Islamic economics] was strongly politically motivated since its very creation and this legacy has never been overcome" (Šrámek 2009, p. 137), with three consequences: (a) Persistence on the literal interpretation of what the theology of Islamic law implies socioeconomically, to this theologically induced but fruitless bottom-up approach to the Islamic political economy, (b) Rejection subsequently of the core western economic principle of "homo economicus - absence of exploitation through competition", though the bond "homo economicus absence of riba al-fadl exploitation" is as unbreakable as the nucleus of the atom when interaction is non-coercive once things are seen top-down and once this riba does not refer to bilateral bargaining, (c) Rejection, because of inability to realize that ruined the peoples in the West by their prolonged interChristian bigotry, they were too weak to raise effective resistance against the ruthless capitalist exploitation that came next to reign over the ruins - distorting these principles to mean capitalist control by divine right - and that only recently the European welfare state emerged as one successful way of restoring these principles and hence, as a way worth followed by Islam as well, given a topdown approach to the Islamic polity.

Now, the financial part, which is centered on the prohibition of riba (exploitation) in in financial transactions, comes as such to complete the picture of the Islamic economy we have been drawing until now. An interest-free mandate is indispensable to the smooth working of a welfare state in general, but much more so in an Islamic economy as a moral imperative. It is equivalent to a full-reserve banking system, advanced originally by the Old, pre-WWII Chicago School of Economics (see e.g. Fisher 1936) as a policy tool against destabilization from the financial system. Contemplating such banking literally, the matter of financially induced destabilization is indeed resolved, but the implementation of a $100 \%$ reserve rule in practice suffers from many weaknesses (see e.g. Diamond and Dybvig 1986). Nevertheless, what is of primary concern to Old Chicago is to nullify the instability, which is caused by commercial bank seigniorage, and Soldatos and Varelas (2014) observe that it does not take necessarily a full reserve requirement to neutralize this seigniorage.

The connection of riba (and usury) with interest rate is no different methodologically than the connection between commercial bank seigniorage and full reserves. This seigniorage reflects the exploitive gains made in financial business too, and the abolition of riba refers to the abolition of the seigniorage, not necessarily of interest rate charges. As very accurately Shams (2004) documents via 
Quranic verses, it is the exploitation, usury or riba, through the manipulation of the interest rate and not the rate per se, which is condemned. Indeed, Soldatos and Varelas (2014) establish that there is a locus of lending and deposit rate combinations all consistent with zero commercial bank seigniorage. This is very important for two reasons. First, because it legitimizes interest rate banking on the part of Islamic banking and shifts the task of seigniorage nullification to the monetary authority as one of interest rate policymaking; a task "as necessary as fire codes on urban buildings", Krugman (2010) might say. And, second, by doing so, it holds a view of Islamic banking having merit not by itself but within the broader Islamic-welfare-state goods-cum-money market riba nullification. This is perhaps the reason why: "Islamic banking does not stand up to its own claims and even more so in those countries where Islamization of economy was imposed by the government" (Šrámek 2009, p. 137).

A bottom-up Islamization, one should notice, whereas what is proposed herein is a top-down Islamization! And, this Islamization does have plenty of room for political democracy as well, which is the last but very important point that needs to be discussed though briefly. Lijphart (1999) documents empirically that the role of political institutions is not so much about macroeconomic outcomes, including budget deficits. Yet, Riba nullification is intimately related to the politics of an Islamic welfare state as follows. As Huber et al. (1993) argue, presidentialism, as well as majoritarian elections, disperse political power and attract a variety of sources of influence on public policy, hampering subsequently welfare-state expansion. At the other end, Tsebelis (2002) notes that the greater tax incidence under minority and coalition governments, (the so-called "common-pool problem), makes government crises more likely and empirically more frequent under proportional elections, inducing greater policy myopia. So, the crucial aspect of an Islamic constitution, setting the rules of the delegation game between voters and politicians, is prescribing rules for government formation and dissolution under a proportional rather than presidentialist or majoritarian system, with the greater instability of the proportional system taken care by riba nullification.

Riba or commercial bank seigniorage neutralization is a must because a proportional electoral rule is a must for still another reason beyond this rule's greater compatibility with the welfare state. The need for such a tenet derives additionally from the fact that a mechanism is needed to be addressing minority vetoing in a non-coercive manner and effectively. A (codified) Islamic welfare-state constitution is a single document writing down the set of fundamental principles and established precedents whereby an Islamic welfare state should be governed. And, if tribal and/or religious minority issues are present, the constitution will become "null and void" in practice if there are not the institutionalized mechanisms of power control needed for the protection of the interests of minorities. And, the key mechanism revolves certainly about the presence of political parties, operating under a proportional electoral canon. Who would protect from arbitrary for some interpretations of constitutional principles and precedents if not political parties accountable to society for their actions?

\section{References}

Ahmad, Imad A. (1994), "An Islamic Perspective on the Wealth of Nations", Minaret of Freedom Preprint Series 96-4. http://www.minaret.org/malaysia.htm

Azid, Toseef (2010), “Anthology of Islamic Economics: Review of Some Basic Issues”, Review of Islamic Economics, 13(2), 165-194.

Carlyle, Thomas (1904[1849]), "Occasional Discourse on the Negro Question", in The Works of Thomas Carlyle, vol.29, 348-383, Charles Scribner's Sons, New York.

Chaudhry, Muhammad Sharif (1999), Fundamentals of Islamic Economic System, Chapter 17, Burhan Education and Welfare Trust, Lahore, Pakistan. http://www.shaufi.com/b16index.htm

Diamond, Douglas W. and Philip H. Dybvig (1986), "Banking Theory, Deposit Insurance, and Bank Regulation", The Journal of Business, 59(1), 55-68. 
Dunning, David, ed. (2011), Social Motivation, Taylor \& Francis, New York.

Eichengreen, Barry (1992), Golden Fetters: The Gold Standard and the Great Depression, 1919-1939, Oxford University Press, New York.

Ekelund, Jr., Robert B. and Robert F. Hébert (2014), A History of Economic Theory and Method, (6th ed.), Waveland Press, Long Grove, IL

Evensky, Jerry (1993), "Retrospectives - Ethics and the Invisible Hand", Journal of Economic Perspectives, 7(2), 197-205.

Evensky, Jerry (2005), “Adam Smith's 'Theory of Moral Sentiments': On Morals and Why They Matter to a Liberal Society of Free People and Free Markets”, Journal of Economic Perspectives, 19(3), 109-130.

Feinberg, Joel (1986), Harm to Self, Oxford University Press, Oxford.

Ferragina, E. et al. (2015), “The Four Worlds of 'Welfare Reality' - Social Risks and Outcomes in Europe", Social Policy and Society, 14 (2), 287-307.

Fisher, Irving (1936), "100\% Money and the Public Debt”, Economic Forum, Spring Number, 406442.

Fried, Barbara H. (1998), The Progressive Assault on Laissez Faire: Robert Hale and the First Law and Economics Movement, Harvard University Press, Cambridge, MA.

Friedman, Gerald (2001), "The Sanctity of Property Rights in American History”, University of Massachusetts Amherst PERI Working Paper No. 14.

http://scholarworks.umass.edu/cgi/viewcontent.cgi?article=1008\&context=peri_workingpapers

Gummi, Umar Muhammad (2013), “The Islamic Welfare State: The Basic Imperatives Toward a Better Society". http://ssrn.com/abstract=2393588

Holmes, George, ed. (1988), The Oxford History of Medieval Europe, Oxford University Press, Oxford.

Huber, Evelyn, Charles Ragin and John D. Stephens (1993), "Social Democracy, Christian Democracy, Constitutional Structure, and the Welfare State", American Journal of Sociology, 99(3), 711-749.

Kennedy, Garvin (2009), “Adam Smith and the Invisible Hand: From Metaphor to Myth”, Economic Journal Watch, 6(2), 239-263.

Khan, M. Akram (1987), "Methodology of Islamic Economics", Journal of Islamic Economics, 1(1), 17-33.

Krugman, Paul (2010), "Financial Reform Endgame”, The New York Times, Feb 28, 2010. http://www.nytimes.com/2010/03/01/opinion/01krugman.html?_r=0

Lijphart, Arend (1999), Patterns of Democracy: Government Forms and Performance in Thirty-Six Countries, Yale University Press, New Haven, CT.

Locke, John ([1690] 1952), The Second Treatise of Government, Bobbs-Merrill, Indianapolis.

Mahomedy, Abdulkader Cassim (2013), "Islamic Economics: Still in Search of an Identity", International Journal of Social Economics, 40(6), 556-578. 
Mehrdad, Valibeigi (1993), "Islamic Economics and Economic Policy Formation in Post-revolutionary Iran: A Critique”, Journal of Economic Issues, 27(3), 793-812.

Mauss, Marcel (1970), The Gift: Forms and Functions of Exchange in Archaic Societies, Cohen \& West, London.

Nasr, S.V.R. (1989), “Towards a Philosophy of Islamic Economics”, Hamdard Islamicus, 12(4), 45-60.

Nora, Pierre (1997), Realms of Memory, Columbia University Press, New York.

Phillip, Thomas (1990), “The Idea Of Islamic Economics”, Die Welt des Islams, 30, 117-139.

Piketty, Thomas (2014), Capital in the Twenty-First Century, Belknap Press, Cambridge, MA.

Pogge, Thomas W. (2008), World Poverty and Human Rights, (2nd ed), Polity Press, Cambridge, UK.

Raines, J. Patrick and Clarence R. Jung (1986), "Knight on Religion and Ethics As Agents of Social Change: An Essay to Commemorate the Centennial of Frank H. Knight's Birth", American Journal of Economics and Sociology, 45(4), 429-439.

Roberts, S. Craig, ed. (2011), Applied Evolutionary Psychology, Oxford University Press, Oxford.

Sen, Amartiya K. (1977), "Rational Fools: A Critique of the Behavioural Foundations of Economic Theory", Philosophy and Public Affairs, 6(4), 317-344.

Shams, Rasul (2004), “A Critical Assessment of Islamic Economics”, Hamburg Institute of InternationalEconomics (HWWA) Discussion Paper 281.

http://ageconsearch.umn.edu/bitstream/26295/1/dp040281.pdf

Soldatos, Gerasimos T. and Erotokritos Varelas (2014), “A Letter on Full-Reserve Banking and Friedman's Rule in Chicago Tradition”, Credit and Capital Markets - Kredit und Kapital, 47(4), 677687.

Šrámek, Ondřej (2009), “Islamic Economics: New Economic Paradigm, or Political Agenda?”, New Perspectives on Political Economy, 5(2), 137-167.

Tsebelis, George (2002), Veto Players: How Political Institutions Work, Princeton University Press, Princeton, NJ.

Zamagni, Stefano, ed. (1995), Altruism between Homo Economicus and Homo Ethicus: A review of The Economics of Altruism, Elgar, Aldershot, UK.

Zaman, Asad (2008), "Islamic Economics: A Survey of the Literature”, University of Birmingham Working Paper 22-2008. http://epapers.bham.ac.uk/1538/1/Zaman_IslamicEconomics.pdf 